\title{
Baranya megyei német népmesék a nemzetiségi oktatásban
}

\section{Az Ördögcsúcs címü mesekötet}

\author{
Márkus Éva \\ ELTE Tanitó- és Óvóképzö Kar Idegen Nyelvi és Irodalmi Tanszék
}

\begin{abstract}
Absztrakt
A tanulmány bevezetőjében bemutatja a magyarországi németek népmeseköteteit (Korb Angéla, Josef Michaelis, Herger Ede, Elli Zenker-Starzacher), majd behatóbban foglalkozik baranyai német népmesékkel, az Ördögcsúcs (Teufelsgipfel) címü mesekötet bemutatásán keresztül. Kiemel egyes népmesei motívumokat, bemutatja többek között a mesék jellemző szereplőit és színtereit. Ezek után a népmesék nemzetiségi oktatásban betöltött szerepét ábrázolja, elemezve azokat a dokumentumokat, amelyek a hazai németség oktatásában-nevelésében szerepet játszanak (Gyökerek és szárnyak, tanmenetek és kerettantervek, 17/2013. EMMI rendelet). Végezetül utal a mesék korszerű, általános iskolai módszertani feldolgozási módjaira.
\end{abstract}

Kulcsszavak: magyarországi németek, népmese, mesekötet, nemzetiségi oktatás, Baranya

\section{Bevezetés}

A mese az irodalom legősibb és legfantasztikusabb műfaja. A 20. században pszichológusok a mese fejlesztő, fejlődést segítő hatásait hangsúlyozták. Ez alapozta meg a mesepedagógiát, ami a mese személyiségfejlesztő hatását is elismeri (Geister, 2014, p. 6-7). A romantika fedezte fel a mesét, amely a mai napig az olvasókönyvek és iskolai tankönyvek szerves része. A 19. század végén Tuiskon Ziller (1817-1882) volt nagy hatással a meseoktatásra, ő dolgozta fel elöször didaktikusan a meséket az iskolai oktatás számára. Abból indult ki, hogy a gyermeknek fejlődése során az emberiség történetének kultúrtörténeti szakaszait be kell járnia. Ezen szakaszok egyike a mesék világa (Geister, 2014, p. 55). A 20. században a tanárok a reformpedagógiai törekvések, a müvészeti nevelési mozgalom kapcsán a mesét műalkotásnak tekintették, esztétikai értelemben, nemcsak tanító-moralizáló értelemben 
közvetítették diákjaik felé. A Waldorf-pedagógiában például fontosnak tartják, hogy a meséket nem kell megmagyarázni, inkább hagyni kell őket hatni a gyermekre (Geister, 2014 p. 58-59). Bruno Bettelheim (1903-1990) számára a mesék főképpen jellemző emberi problémákról szóló történetek, melyek azt ábrázolják, hogy az emberek hogyan szembesülnek a fejlődésük feladataival, és hogyan küzdik le ezeket. És mivel a meséknek majdnem mindig jó a végük, a fiatal mesehallgatók bátorságot merítenek a saját fejlődésük feladataival való megbirkózáshoz. A meséket az idegennyelvi, célnyelvi fejlesztésben is jól lehet használni: az érzelmi, művészeti neveléssel kiváló eredményeket érhetünk el, használjuk bátran a gyermekek kreativitását (bővebben lásd Márkus, 2017a).

\section{A magyarországi német népmesekötetekről}

Magyarok és németek a Kárpát-medencében már ezer éve élnek együtt, a németek a magyar államalapítás óta jelen vannak az országban. A 10. században István király felesége, Gizella bajor hercegnő német lovagok, papok és parasztok kíséretében jött az országba, akik részt vállaltak a kereszténység elterjesztésében, a központi királyi hatalom megszilárdításában, és a nyugati minták alapján püspökségekre és vármegyékre épülő egyházi és világi közigazgatási struktúra létrehozásában. A 13. század elejére kialakultak az erdélyi és a szepességi szász települések. A 18. században a török háborúk befejezése után több hullámban települtek be németek Magyarországra. A földművelő német parasztok felszántották a parlagon heverő síkságokat, meghonosították a gabona-váltógazdálkodást, a trágyázást, az istállós állattartást és új kultúrnövények termesztését. A második világháború után a kollektív bủnösség elve alapján eldöntötték a németek Magyarországról való „kitelepítését”. 220000 németnek mennie kellett, körülbelül ugyanennyi maradhatott. 1946-ban 120000 embert űztek el Magyarországról az amerikai megszállási övezetbe, Baden-Württembergbe, Bajorországba és Hessenbe, 1947-1948-ban pedig újabb ötvenezret a szovjet megszállási övezetbe. Az elüzés, az azzal járó jogfosztás, kisajátítás, diszkrimináció és demoralizálás a legtöbb faluban és városban teljesen szétrombolta az etnikai együttélés hagyományos formáit (Seewann, 2013). A magyarországi németek jelenleg az ország második legnagyobb nemzetisége.

Több olyan gyüjteményes mesekötet is megjelent (nemcsak Magyarországon), amely a magyarországi németek népmesekincsét tartalmazza. Elsőként egy nyelvjárásban íródottat, egyben a legfrissebben megjelentet említem: $A$ szomorúfüz gazdagsága (Reigöd vum Weidepam) címüt. A 2011-ben a Neue Zeitung Stiftung gondozásában megjelent 80 oldalas, 24 mesét tartalmazó mesekötet káni (Baranya megye) nyelvjárási szövegeket tartalmaz, melyeket Korb Angéla gyüjtött a nagymamájától, Mathilde Geiszkopftól. A könyv melléklete egy $\mathrm{CD}$, amin az eredeti hangfelvételek hallgathatók meg. A kötet végén pár oldalas nyelvjárási szótár is található. 
Josef Michaelis, villányi tanár és író 2008-ban adta ki magánkiadásban Az elveszett kincs: mesék és mondák (Der verlorene Schatz: Märchen und Sagen) címen a villányi (Baranya megye) népmeséket, mondákat és legendákat. A 177 oldalas kötet kétnyelvü, magyar és német nyelven olvashatjuk a meséket. A kötet elején a szerző saját állatmeséit olvashatjuk, majd a 70. oldaltól találhatók a mondák, például a villányi kőcsigákról, a Csillagvölgyről, a Remete-dülőről, a Törökdombról vagy a Rabló-rétről. A címadó $A z$ elveszett kincs egy török időkről szóló mondát dolgoz fel, melyet a szerző édesapja elmeséléséből ismert meg. A kötetet Bruszt Nóra villányi diáklány illusztrációi színesítik.

1984-ben, Budapesten jelent meg az Ördögcsúcs (Teufelsgipfel) című mesekötet. Herger Ede palkonyai (Baranya megye) német nyelvü népmeséket gyűjtött benne össze. A gyüjtemény 2000-ben kétnyelvü (magyar és német) kiadásban is megjelent Pécsett, 20 mesét tartalmaz. Ezt a kötetet a következő fejezetben ismertetjük részletesebben.

Karl Vargha és Rónai Béla Der schlaue Bergmannsknappe. Märchen der Bergleute aus dem Komitat Baranya (Südungarn) címmel Budapesten adta közre 1973-ban a Baranya megyei bányászok meséit és mondáit. Ezekben a mesékben a földalatti világ, a sziklák, a barlangok, földalatti vízfolyások és bányák a mesék helyszíne, melyeket gazdagon népesítenek be a fantázia szülte mesehősök. Bepillantást engednek a kemény bányászlétbe, bemutatják a gondokat, vágyakat, a megvívott harcokat és az örömöket is. A mesék között vannak eredetmagyarázó és a településnevek eredetét magyarázó mesék is. A meséket Pécsbányatelepen, Alsó- és Felsőbánomon, Mecsekszabolcson, Vasason, Hosszúhetényben, Nagymányokon, Komlón és Szászváron gyűjtötték.

Elli Zenker-Starzacher osztrák mesekutatónő a Vértes-hegység és a Bakony eldugott sváb falvaiban (többek között Kozma, Kecskéd, Bakonykoppány, Gánt, Alsógalla, Balinka településeken) kutatott a múlt század első felében, népmeséket gyüjtött. Kutatásai eredményeként a következő mesekötetek jelentek meg Németországban, illetve Ausztriában:

- Elli Zenker-Starzacher (1941). Eine deutsche Märchenerzählerin aus Ungarn. Hoheneichen-Verlag, München.

- Elli Zenker-Starzacher (1956). Es war einmal. Deutsche Märchen aus dem Schildgebirge und dem Buchenwald. Prodomo-Verlag, Wien.

- Elli Zenker-Starzacher (1986). Märchen aus dem Schildgebirge. Deutsches Erzählgut aus Ungarn. Carinthia, Klagenfurt.

Az 1941-ben megjelent könyv kizárólag egy adatközlő meséit közli. Az 1956-ban megjelent kötetet Erna Moser-Piffl illusztrálta, aki Bécsben festészetet tanult, és a tanulmányi szünetekben Elli Zenker-Starzacherrel együtt látogatott Magyarországra. Míg Elli meséket jegyzetelt, addig Erna lerajzolta az embereket, akik akkor még a Vértes-hegység és a Bakony eldugott sváb falvaiban hagyományos népviseletet hordtak. Mind az itt hallott régies nyelvjárás, mind az itt látott népviselet régmúlt idők kincsét jelentette a bécsi hall- 
gatónők számára. Míg az 1941-es kötet egyetlen mesemondó asszony meséit tartalmazza, addig az 1956-os kötetben több mesemondó meséi is megjelennek. A kötet különlegessége, hogy nem csupán a meséket írja le Zenker-Starzacher, hanem a mesemondókat is egyenként, részletesen bemutatja, mert azt vallja, hogy a mese élőszóban elmondva az igazi, leírt formájában nem tudja ugyanazt az érzést visszaadni, mint amikor hallhatjuk is, és az élőszavas mesélés élményét kísérelte meg némiképp visszaadni az olvasó számára. Meséltek neki gyerekek és idősek, férfiak és asszonyok, foglalkozásuk szerint cipész, éjjeli őr, kisbíró, bányász, szőlőcsősz és gyári munkás. Az 1956-ban megjelent kötet összesen 30 mesét tartalmaz. Az 1986-ban megjelent harmadik kötet kizárólag a Vértes-hegység falvainak meséivel foglalkozik.

\section{Az Ördögcsúcs (Teufelsgipfel) címü mesekötet}

A következőkben az Ördögcsúcs című kötet meséit mutatjuk be részletesebben. A meséket a Baranya megyei Palkonyán gyüjtötték. Palkonya a Villányihegységtől északra fekszik, dombos vidéken. A település a múlt században egyetlen utcából állt, melynek két oldalán jellegzetes sváb parasztházak álltak. Lakói mezőgazdasággal és állattenyészéssel foglalkoztak. 1296-ból származik a település első okleveles említése. Miután a török-kor végével nagyon megfogyatkozott a lakók száma, 1746-ban német telepesek érkeztek a faluba. Ök bajor-frank keveréknyelvjárást beszélnek. A második világháború előtti időkig ők laktak többségében a településen, jellegzetes sváb népviseletet hordtak (Herger, 1984). A második világháború utáni kitelepítések nyomán ez jelentősen megváltozott. Ma már nem járnak népviseletben és 2001-ben már csak a lakosság 6,2\%-a vallotta magát német nemzetiségünek. Ez a szám 2011-ben 23\%-ra nőtt. Palkonya pincesora 53, müemlékké nyilvánított présházból áll. Herger Ede, a mesék gyűjtője palkonyai származású tanár, szőlősgazda. A helyi német nyelvjárás kutatásával is foglalkozik, a 18. században bevándorolt német lakosság nyelvjárásának hangtanát elemezte diplomamunkájában ${ }^{1}$

Az Ördögcsúcs című kötet meséi általában falusi környezetben játszódnak, és a szegény emberek életéről szólnak, sokszor tréfával, humorral füszerezve. A fiúgyermekek sokszor útra kelnek benne, elmennek szerencsét próbálni, eközben eljutnak messzi városokba, országokba is, és ott nem ritkán király lesz belőlük, miután számos, nehéz próbát kiálltak, például legyőzték a hétfejű sárkányt. Találkozunk rablóbandával is, akik a sürü, sötét erdőben tanyáznak, és varázslatos kincseik vannak, úgy mint egy vörös nadrág (amelyet, ha megráznak, arany hullik belőle), hétmérföldes csizma, egy olyan sapka, ami mindenfelé lö, ha megforgatják, vagy egy szurony, amit, ha a földbe szúrnak, akkor katonai ezredek masíroznak elő a földből.

Egyéb varázslatos tárgyak is szerepelnek a mesékben, mint például egy erszény, amiből soha nem fogy ki a pénz, egy arany gyürü, amelyet, ha elfor-

\footnotetext{
${ }^{1}$ https://hu.wikipedia.org/wiki/Palkonya
} 
dítanak, kívánhatnak bármit a világon, vagy egy körtefa, amely gyümölcséből, ha eszik, szarva nő az embernek, és az almafa, amely gyümölcséből, ha fogyasztanak, eltűnik a körte által növesztett szarv az ember fejéről.

A gonosz fogadós (és a felesége, valamint a lánya) is megjelenik a mesékben, aki leitatja a gyanútlan vendéget, általában a legkisebb fiút, majd ellopja a varázskincseit. Ezeket a legkisebb fiú hiába kéri vissza, csak egy újabb varázslatos tárgy segítségével sikerül visszaszereznie. A fogadós(feleség) természetesen megfizet a mese végén, elnyeri méltó büntetését.

Egy másik mese hőse a molnárfiú, aki olyan erős, hogy tálca híján egy malomkövön kínálja az arra járó királynak a pohár vizet. A király meghívja őt a seregébe harcolni, majd miután győz a sereg, jutalmul neki adja a lányát feleségül. Találkozunk a szegény és a gazdag paraszt szembenállásával is. A gazdag paraszt irigy és kapzsi, és természetesen pórul jár a mese végén, míg a jóságos, melegszívü szegényember elnyeri méltó jutalmát, mesés aranykincs formájában.

Boszorkányokkal is találkozunk, akik a sűrü, sötét erdő mélyén élnek. Hőseink néha szolgálatukba szegődnek. A legkisebb fiúk mesehősként lelepleznek, sőt megölnek rablóvezéreket is, majd a rengeteg felfedezett kincset jelentik a hatóságoknak, akik bátorságukért és becsületességükért busásan megjutalmazzák őket. A legkisebb fiút fivérei sokszor kihasználják, maguk helyett dolgoztatják, de elnyerik méltó büntetésüket, a legkisebb pedig jutalmat kap a mese végén és győzedelmeskedik.

Az engedetlen Andriskáról szóló mesében az elkószáló Andriskát az erdőben rablók fogják el, és arra használják a kistermetű fiút, hogy a rablásaik során bemásszon kis ablakokon, és lopjon a házakból - jellemzően például stifolder nevü kolbászt, ami a Baranya megyei svábok jellegzetes és hagyományos étele. Természetesen felteszi magának a kérdést a fiú, hogy miért is volt olyan engedetlen. Mikor egyszer a saját házába küldik Andrist rabolni, felismeri a családja, és így szerencsésen megmenekül. Jelentik a rendőröknek a rablóbandát, akiket letartóztatnak, és ezután már Andris is engedelmes fiúként viselkedik egész életében.

Fantasztikus mesékkel is találkozunk a kötetben, például egy repülő lóval, aki miután kimúlik és lenyúzzák a bőrét, bekenik libazsírral, tollakat és szárnyakat növeszt, majd repülni kezd. A mesehős pedig egy alkalommal olyan mélyen fúródik a földbe, hogy nem tud kimászni, ezért hazamegy, hoz egy ásót, majd azzal kiássa magát.

Királyokról, királynékról és királyfikról szóló mesék is vannak a gyűjteményben, akik kastélyban laknak. Az egyik mesében a gonosz királyné kicseréli fiatal menye hetesikreit kiskutyákra. A gyerekeket az erdőben egy remete nevelte fel. A lányok később hattyúvá változnak. A mese végén fény derül az igazságra, és a gonosz királynét halálra ítélik, majd máglyán elégetik. Egy, a büszke királyról szóló másik mesében a király nem akarja, hogy lányai férjhez menjenek. A lányok természetesen nagyon szeretnének férjhez menni, lányfejű hallá változnak, és csak udvarlóik segítségével sikerül visszaváltozniuk leánnyá. A büszke királynak megbocsátanak a mese végén. 
A csodahegedűről szóló mese hőse a cigányember, a felesége és a gyerekek. A cigányember az ördögtől kapja a csodálatos hegedüt, amellyel megbünteti a legkisebb fia a fukar grófot, aki nem akart a muzsikaszóért fizetni. A körtefából faragott varázshegedü egy másik mesében emberi hangon énekel, és a segítségével lepleződik le a gonosz királyné, aki megölte a mostohalányát. Öt is elégetik a máglyán, a megölt királykisasszony pedig feltámad, és boldogan él apjával tovább.

A favágócsalád is megjelenik szereplőként a mesékben, ők egy magas hegyen élnek. Miután meghal az édesanya, az apa egyedül marad a két fiával. Egy napon, mikor a nagyobbik fiúnak kell vigyáznia a kisebbre, kitör egy zivatar, és a kisfiú eltűnik. Egy grófnő talál rá, akinek nincs saját gyermeke, ezért magához veszi és felneveli. Évek múlva a fiú újra találkozik elveszett családjával, és magához veszi őket a grófi palotába.

A kötetet a Menyasszonytánc című tréfás mese zárja, amiben az idős házaspár rájön, hogy még nem táncolták el a menyasszonytáncot. Mikor ezt megteszik, találnak egy erszényt. Az arra járó grófnő rákérdez, hogy nem találtak-e egy erszényt, mire ők azt válaszolják, hogy találtak, mikor a menyasszonytáncot járták el. Erre a grófnő csak legyint, hogy az biztos már nagyon régen lehetett, és tovább hajt. A szegény, sokgyermekes házaspár így megtartja az erszényt, és attól fogva gazdagok lesznek.

\section{Népmesék a német nemzetiségi oktatásban}

A magyarországi németek nyelvjárási népköltészete lírai és prózai művekből áll. Nélkülözhetetlen, hogy e népköltészeti alkotások a német nemzetiség közoktatásában és -nevelésében is megjelenjenek. Módszertani szempontból a lírai népköltészeti alkotások vannak előnyben, hiszen egy néhány strófából álló népdal, kiszámoló, mondóka a nemzetiségi irodalom- vagy népismeret órán kompaktabb módon és rövidebb idő alatt dolgozható fel, mint egy bonyolultabb dramaturgiával, összetett szociális hálóval bíró népmese. Nem csoda, ha a magyarországi német nyelvjárások tanórai felbukkanásával, a nyelvjárási lírai művek interpretációjával, tantárgypedagógiai lehetőségeivel több tanulmány foglalkozott, mint népmesék hasonló felhasználásával (lásd például Kerekes, 2013; 2017, 2019)

A következőkben először számba vesszük, hogy a hivatalos oktatási dokumentumok milyen ajánlásokat fogalmaznak meg a népmesék tanításával kapcsolatban. A Gyökerek és szárnyak, kompetenciamodell a német nemzetiségi oktatás számára című dokumentumban a mesék az országismereti-interkulturális kompetenciaterületen belül jutnak szerephez (Árendásné et al., 2011).

A 17/2013. (III. 1.) EMMI rendelet a nemzetiség óvodai nevelésének irányelve és a nemzetiség iskolai oktatásának irányelve kiadásáról című dokumentum az 5-8. évfolyamon ajánlja a következő szerzőket és műveket feldolgozásra - köztük a német népmeséket is, például a tanulmányban korábban említett Herger Ede és Josef Michaelis szerzők meseköteteit: 
“6.9. Szerzők és művek.

- Epika: magyarországi német és német népmesék, mümesék, mondák (pl. Grimm: Kinder- und Hausmärchen; Märchen von Janosch, Ede Herger, Karl Varga, Josef Michaelis); hazudós történetek (pl. Münchausen²)."

A közmüveltségi tartalmak között a fent említett EMMI rendelet az 1-4. évfolyamon a tanulási képesség fejlesztése okán a népmesék hangos könyveit ajánlja, 5-8. évfolyamon pedig a következő szerzőket és müveket - köztük a népmeséket is, például a Teufelsgipfel (Ördögcsúcs) címü kötetet:

\section{"6.2. Irodalom}

- Népköltészet: német és magyarországi német mondókák, népdalok, népi játékok, népmesék, mondák, közmondások.

- Magyarországi német szerzők versei, meséi, elbeszélései. Szerzők: pl. Erika Áts, Georg Fath, Josef Michaelis, Engelbert Rittinger, Valeria Koch. Gyűjtemények: Igele-Bigele, Zauberhut, Jahresringe, Teufelsgipfel ${ }^{3}$ ".

A tanterveket, tanmeneteket elemezve feltűnik, hogy a Magyarországi Németek Pedagógiai Intézete honlapján (UDPI) a német népismeret tárgy 1-4. osztály számára készült tanulási tartalmai között nem említik a népmeséket. A nyelvoktató iskolák számára az 5. osztályban ajánlják a helyi tantervben a Der arme und der reiche Bauer című népmese feldolgozását, amely a szegény és a gazdag parasztról szól, a korábbiakban ejtettünk szót róla. A tanulónak ezzel kapcsolatban a következő kompetenciákat kell elsajátítania: tudnia kell meséket olvasni, előadni, kreatív írásos feladatokat végrehajtani, és egy hagyományos meséről képregényt készíteni/rajzolni ${ }^{4}$.

A 2020-ban életbe lépett új Nemzeti alaptantervhez az illeszkedő tartalmi szabályozók, az új kerettantervek is megszülettek, vizsgálódásunk szempontjából most a német nemzetiségi nevelés-oktatás kerettantervei ${ }^{5}$ az érdekesek. Az anyanyelvü és kétnyelvü iskolák számára kiadott német nyelv és irodalom tantárgy kerettanterve alsó tagozaton nem tartalmazza a népmeséket. 5-6. osztályban kerülnek elő először a népmesék, a Grimm: Kinderund Hausmärchen-t, vagyis a Grimm-meséket és a Der überlistete Teufel (In Herger Ede: Der Teufelsgipfel), a friss, 2020-ban megjelent kerettanterv pedig $A$ rászedett ördög című mondát ajánlja feldolgozásra.

A német nemzetiségi pedagógusképzés hallgatói számára megjelent német gyermekirodalmi jegyzetben (Márkus, 2007) is megtaláljuk a népmeséket. A 4. fejezet foglalkozik a Teufelsgipgel. Ungarndeutsche Volksmärchen

\footnotetext{
${ }^{2}$ http://www.kozlonyok.hu/nkonline/MKPDF/hiteles/MK13035.pdf

${ }^{3}$ http://www.kozlonyok.hu/nkonline/MKPDF/hiteles/MK13035.pd

${ }^{4}$ http://www.udpi.hu/de/tantervek

${ }^{5}$ http://www.udpi.hu/hu/tantervek; https://www.oktatas.hu/kozneveles/kerettantervek/2020_ nat/nemzetisegi_neveles_oktatas_kerettantervei/nemet
} 
für Kinder címü kötettel, annak néhány meséjét mutatja be, didaktizált formában, módszertani ajánlásokkal; az 5. fejezet pedig a Der schlaue Bergmannsknappe. Märchen der Bergleute aus dem Komitat Baranya címet viseli, ez Baranya megyei bányászmeséket és mondákat közöl.

A magyarországi német nyelvű gyermekirodalom történelméről, annak kialakulásáról nyújt részletes áttekintést Klein Ágnes (2013) tanulmánya. A mesék felhasználásához az oktatásban kaphatunk módszertani segédletet, konkrét ötleteket, például Klein Ágnes ésMárkus Éva 2017-es kötetének cikkei, tanulmányai között. Juhász Márta (2017b) egy nyelvjárási mese feldolgozási lehetöségeiről és nehézségeiről ír, ám mindenképpen a nyelvjárás használta mellett érvel az oktatásban (2017a). Márkus Éva (2017b) ugyanebben a kötetben az e tanulmány bevezetőjében említett Baranya megyei, káni nyelvjárásban írt mesék iskolai feldolgozási lehetőségeiről ír. Juhász Márta (2017b) felhívja a figyelmet a magyarországi német nyelvjárások visszaszorulására, ami megnehezíti a nyelvjárási szövegekkel való foglalkozást az iskolában, óvodában. Ráadásul egyes szülők hátrányként is értékelik a nyelvjárással való foglalkozást az iskolában, óvodában. Juhász az érzékenyítést tartja fontosnak, nem a dialektus megtanítását. A magyarországi német nyelvjárások jelenkori, közösségi szintű revitalizációjának lehetőségeivel és korlátaival empirikus szempontból Müller Márta (2010) foglalkozott. A nyelvjárásokkal való foglalkozás az identitás része, azt hivatalos oktatási dokumentumok elő is írják, így nem hagyható el, különösen izgalmas a népismeret tárggyal, a hagyományápolással való összekapcsolása. Módszertani ötletekért: (lásd Erb \& Márkus, 2020). A nemzetiségi német közoktatás körülményeihez lásd Müller (2012), valamint Knipf-Komlósi Erzsébet és Müller Márta (2018.) tanulmányait, a nyelvjárások közelmúltbéli státuszát a nemzetiségi közoktatási dokumentumokban és relevanciájukat az oktatástervezés szempontjából Müller Márta és Knipf-Komlósi Erzsébet 2012-es tanulmánya (2012) elemzi.

Ötleteket meríthetünk a népmesékkel való foglalkozáshoz a többi nemzetiségi nyelv, például a szlovák (vö. Bereczkiné Záluszki, 2014, 2016) vagy akár más idegen nyelv módszertanából (Fehér, 2014; Márkus \& Trentinné Benkő, 2014; Mewald, Klein \& Wallner, 2019; Morvai, 2014; Sárvári, 2014; Szepesi, 2014; Trentinné Benkő \& Szepesi, 2006) is. Az idegennyelvi és kétnyelvi pedagógusképzésben, illetve -kutatásban is fontos szerephez jutnak a mesék (Kovács \& Trentinné, 2003; Trentinné, 2014, 2019).

\section{Összegzés}

A tanulmány röviden bemutatta a magyarországi németek főbb népmeseköteteit, és elemezte ezek megjelenését, szerepét a nemzetiségi nevelésben-oktatásban. Részletesebben került bemutatásra az Ördögcsúcs című népmesegyűjteményes kötet. A magyarországi németek több száz éve élnek együtt a magyarokkal a Kárpát-medencében, történelmük és kultúrájuk több ponton összefonódott. Sokszor hívják őket sváboknak, de az elnevezés nem pontos, mert származásukat tekintve nem azonosak a mai Németország területén 
élő svábokkal. A magyarországi németek száma a második világháború után jelentősen csökkent, anyanyelvüket, nyelvjárásukat sokáig nem használhatták, így a mai, fiatal, iskolába járó generáció a német anyanyelvet és a sváb hagyományokat sokszor az iskolában sajátítja el. Ennek terepei a nemzetiségi iskolák. Ahogy a Steh dazu! A Magyarországi Németek Országos Önkormányzata stratégiája 2020 megfogalmazza: „A német nyelv és kultúra a magyarországi német identitás fenntartásának és megerősödésének alapvető és elengedhetetlen feltétele. Mi, magyarországi németek, nyelvi kisebbségnek tekintjük magunkat. A német nyelv magas szintű ismerete, a helyi nyelvjárások és szokások ápolása, az ismeretek és eszmecserék a magyarországi németek történetéről és jelenéről a német nyelvterület modernkori kultúrájának ismeretével együtt a magyarországi német identitás nélkülözhetetlen részét képezi. Ezt - a nyelvhez és kultúrához hasonlóan - nem lehet statikus rendszerként definiálni. Az identitás folyamatosan, a résztvevők kreatív közremüködésével, valamint a társadalmilag adott lehetőségek kiaknázásával teremtődik újra. A magyarországi német identitás kialakításában, fenntartásában és erősítésében a szülői háttér továbbra is döntő fontosságú, de e folyamatban a nevelési-oktatási intézmények is meghatározó szerepet játszanak."

\section{Irodalom}

Árendásné Huj, K., Fodorné Szöllösi, D., Győriné Meiszter, K., Hock-Englender, I., Nagy, K., Rainer, P., Stecklné Boldizsár, K., Steindl, A. \& Tutti, G. (2011). Wurzeln und Flügel. Kompetenzmodell für den Deutschunterricht der deutschen Nationalitätenschulen in Ungarn. Landesselbstverwaltung der Ungarndeutschen, Ungarndeutsches Pädagogisches Institut, http://udpi.hu/doc/kiadvanyok/wurzeln_und_fluegel/ wuf-kompetenz modell-nationalitaten.pdf

Bereczkiné Záluszki, A. (2014). Nyelvi, kulturális nevelés egy dél-alföldi szlovák nemzetiségi óvodában. In Márkus, É. \& Trentinné Benkő, É. (Eds.), A korai idegen nyelvi fejlesztés elmélete és gyakorlata. Konferenciaelöadások és háttértanulmányok (pp. 158-163). ELTE Eötvös Kiadó.

Bereczkiné Záluszki, A. (2016). Művészeti nevelés és hagyományápolás a tótkomlósi szlovák nemzetiségi óvodában. Gyermeknevelés, 4(1), 172-176. https://doi. org/10.31074/gyntf.2016.1.172.176

Bettelheim, B. (1997). Kinder brauchen Märchen. 20. Auflage..

Erb, M., Englenderné Hock, I., Heltainé Panyik, E., Heves, F., Klein, Á., Knáb, E., Manz, A., Manzné, Jäger, M., Müller, M., Rainer, P., Seiler, H. \& Szauer, Á. (2010). Gyökerek és szárnyak. A magyarországi németek nevelési, oktatási és közmüvelödési programja. Budapest.

Erb, D. \& Márkus, É. (2020). Traditionsbewahrung in Großnaarad/Nagynyárád. Der erlebnisreiche Volkskundeunterricht im Sinne der lebendigen Traditionsbewahrung in Großnaarad. In Vitályos, G. Á. (Ed.), Mester és tanítvány VI. (pp. 21-34). ELTE Eötvös Kiadó. http://www.eltereader.hu/media/2020/04/MesterEsTanitvanyVI_webre.pdf 
Fehér, J. (2014). A British Council Családi Angol programja Magyarországon. In Márkus, É. \& Trentinné Benkő, É. (Eds.), A korai idegen nyelvi fejlesztés elmélete és gyakorlata. Konferenciaelöadások és háttértanulmányok (pp. 107-116). ELTE Eötvös Kiadó.

Geister, O. (2014). Kleine Pädagogik des Märchens. Begriff - Geschichte - Ideen für Erziehung und Unterricht. Schneider Verlag.

Herger, E. (2000). Ördögcsúcs. Veranda.

Herger, E. (1984, Ed.). Teufelsgipfel. Ungarndeutsche Volksmärchen für Kinder. Gesammelt in Palgan/Palkonya (Kom. Branau) von Ede Herger. Tankönyvkiadó.

Juhász, M. (2017a). Mundartliteratur im Deutschunterricht - aber was und wie?! In Klein, Á. \& Márkus, É. (Eds.), Ungarndeutsche Kinderliteratur in Theorie und Praxis. Didaktische Handreichung für Pädagog_innen zum Unterricht der ungarndeutschen Nationalitätenkinderliteratur im Kindergarten und in der Primarstufe (pp. 20-28). Bolko-Print Kft.

Juhász, M. (2017b). Möglichkeiten zur sprachlichen Bearbeitung eines Mundartmärchens. In Klein, Â. \& Márkus, É. (Eds.), Ungarndeutsche Kinderliteratur in Theorie und Praxis. Didaktische Handreichung für Pädagog_innen zum Unterricht der ungarndeutschen Nationalitätenkinderliteratur im Kindergarten und in der Primarstufe (pp. 50-57). Bolko-Print Kft.

Kerekes, G. (2013). Rolle und Funktion der Mundart in der ungarndeutschen Literatur. In Knipf-Komlósi, E., Öhl, P., Péteri, A. \& V. Rada, R. (Eds.), Dynamik der Sprache(n) und Disziplinen: 21. internationale Linguistiktage der Gesellschaft für Sprache und Sprachen in Budapest (pp. 127-133). ELTE Germanisztikai Intézet.

Kerekes, G. (2017). Im Widerstreit der Traditionen: Die Rolle des Dialekts in der ungarndeutschen Literatur. In Philipp, H. \& Ströbel, A. (Eds.) Deutsch in Mittel-, Ost- und Südeuropa: Geschichtliche Grundlagen und aktuelle Einbettung (pp. 347-360). Verlag Friedrich Pustet.

Kerekes, G. (2019). Bairische Dialektreime im Deutschunterricht. In Bordás, S. (Ed.) Módszerek és teóriák (pp. 163-176). Eötvös József Főiskola.

Klein, Á. (2013). Német nyelvü gyermekirodalom Magyarországon. In Fekete, R., Kurucz, R. \& Nagy, J. T. (Eds.) „Szépet, jót, igazat akarva” Tanulmányok N. Horváth Béla 60. születésnapjára (pp. 86-99). Pécsi Tudományegyetem Illyés Gyula Kar.

Klein, Á. \& Márkus, É. (2017, Eds.). Ungarndeutsche Kinderliteratur in Theorie und Praxis. Didaktische Handreichung für Pädagog_innen zum Unterricht der ungarndeutschen Nationalitätenkinderliteratur im Kindergarten und in der Primarstufe. Bolko-Print Kft., http://udpi.hu/hu/ungarndeutsche-kinderliteraturin-theorie-und-praxis-pdf/file

Knipf-Komlósi, E. \& Müller, M. (2018). Zwischen Vitalität und Aufgabe: Dynamische Aspekte in der Sprache der deutschen Minderheit in Ungarn. In Meier, J. \& Weber, M. (Eds.), Jahrbuch des Bundesinstituts für Kultur und Geschichte der Deutschen im östlichen Europa. Band 26. Sprache (pp. 51-67). de Gruyter. 
Kovács, J. \& Trentinné Benkő, É. (2003/2011/2013). A Task-based Reader on Methodology and Children's Literature: For Students of Primary Teacher Training = Módszertani és gyermekirodalmi szöveg-és feladatgyüjtemény. ELTE Eötvös Kiadó.

Márkus, É. (2017a). A mesepedagógia alkalmazási lehetőségei a kisgyermekkori idegennyelv-fejlesztésben (német jó gyakorlatok). In Márkus, É., M. Pintér, T. \& Trentinné Benkő, É. (Eds.), Jó gyakorlatok a korai idegen nyelvi fejlesztésben és pedagógusképzésben: Oktatás, kutatás, innováció (pp. 36-49). ELTE TÓK.

Márkus, É. (2017b). Praktische Verwendungsbeispiele mundartlicher Texte im Unterricht anhand von Beispielen aus der Märchensammlung Reigöd vum Weidepam. In Márkus É. \& Klein Á. (Eds.), Ungarndeutsche Kinderliteratur in Theorie und Praxis. Didaktische Handreichung für Pädagog_innen zum Unterricht der ungarndeutschen Nationalitätenkinderliteratur im Kindergarten und in der Primarstufe (pp. 58-71). Bolko-Print Kft.

Márkus, É (2007). „Ene bene Tintenfass, geh' zur Schul' und lerne was.” Eine Text-und Aufgabensammlung zur „Ungarndeutschen Kinderliteratur" für die Studenten der NationalitätenkindergärtnerInnen und -grundschullehrerInnenbildung. Trezor Verlag, http://mek.oszk.hu/08800/08816/08816.pdf

Márkus, É. \& Trentinné Benkő, É. (2014, Eds.). A korai idegen nyelvi fejlesztés elmélete és gyakorlata. Konferenciaelőadások és háttértanulmányok. ELTE Eötvös Kiadó. http://pedagoguskepzes.elte.hu/letoltesek/1_markus_trentinne_ korai_idegennyelvi_fejlesztes.pdf

Mewald, C., Klein, Á. \& Sabine, W. (2019). Are you sitting comfortably? About the value of stories in the development of multilingualism and multiliteracies. REE-SOURCE, 11, 1-19, https://journal.ph-noe.ac.at/index.php/resource/issue/view/30

Michaelis, J. (2008). Der verlorene Schatz: Märchen und Sagen. J. Michaelis.

Michaelis, J. (1991). Zauberhut / Varázscilinder. Tankönyvkiadó.

Morvai, E. (2014). Jókedvvel németül. Tanártovábbképzés és tananyagfejlesztés a budapesti Goethe Intézetben különös tekintettel a kisgyermekkori nyelvoktatás területére. In Márkus, É. \& Trentinné Benkő, É. (Eds.), A korai idegen nyelvi fejlesztés elmélete és gyakorlata. Konferenciaelőadások és háttértanulmányok (pp. 214-226). ELTE Eötvös Kiadó.

Müller, M. (2010). Möglichkeiten und Grenzen der Dialekterhaltung in einer ungarndeutschen Gemeinde. In Zimányi, Á. (Ed.), A tudomány nyelve - a nyelv tudománya (pp. 651-658). MANYE - Eszterházy Károly Főiskola.

Müller,M.(2012).Formenund Nutzendesungarndeutschen Minderheitenunterrichts. In Kerekes, G. \& Müller, M. (Eds.) Traditionspflege und Erneuerung. Perspektiven der deutschen Nationalität in Ungarn im 21. Jahrhundert (pp. 99-116). Ad librum. (= Neue-Zeitung Bücher, Reihe Wissenschaft Bd. 1).

Müller, M. \& Knipf-Komlósi, E. (2012). Mundarten im Minderheitenunterricht in ungarndeutschen Schulen. In Glauninger, M. \& Barabas, B. (Eds.), Wortschatz 
und Sprachkontakt im Kontext oberdeutscher Wörterbücher, Sprachatlanten und Sprachinseln. Werner Bauer zum 70. Geburtstag \& Ortsgrammatiken als Unterrichtsbehelf: „Laiengrammatiken” für Minderheitensprachen (pp. 209-222).

Sárvári, T. (2014). A drámapedagógia alkalmazási lehetőségei a korai idegen nyelvi fejlesztésben. In Márkus, É. \& Trentinné Benkő, É. (Eds.), A korai idegen nyelvi fejlesztés elmélete és gyakorlata. Konferenciaelöadások és háttértanulmányok (pp. 286-306). ELTE Eötvös Kiadó.

Schuth, J. \& Korb, A. (2011, Eds.). Reigöd vum Weidepam. Kaanr Vrzählstickr von Mathilde Geiszkopf (A szomorúfüz gazdagsága. Káni elbeszélések Mathilde Geiszkopftól). Neue Zeitung Stiftung.

Seewann, G. (2013). A magyarországi németek történetének vázlatos áttekintése. Hitel, 26(8), 84-92. http://epa.oszk.hu/01300/01343/00139/pdf/EPA01343_ hitel_2013_08-084-092.pdf

Szepesi, J. (2014). A multikulturalitásra, interkulturalitásra nevelés megjelenése az angolórákon 1-6. osztályig. In Márkus, É. \& Trentinné Benkő, É. (Eds.,) A korai idegen nyelvi fejlesztés elmélete és gyakorlata. Konferenciaelöadások és háttértanulmányok (pp. 255-271). ELTE Eötvös Kiadó.

Trentinné Benkő, É. (2014). Meseelemzés a korai idegen nyelvi fejlesztéssel kapcsolatos pedagógushallgatói nézetek, kompetenciák, tanulási eredmények feltárására. In Márkus, É. \& Trentinné Benkő, É. (Eds.), A korai idegen nyelvi fejlesztés elmélete és gyakorlata. Konferenciaelöadások és háttértanulmányok (pp. 390-411). ELTE Eötvös Kiadó.

Trentinné Benkő, É. (2019). And They Taught Happily Ever After. In Camps-Casals, N., Canals Botines, M. \& Casanovas, N. M. (Eds.), Storytelling Revisited 2018: Gender, Language, Music, Cinema (pp. 87-94). Universitat de Vic - Universitat Central de Catalunya.

Trentinné Benkő, É. \& Szepesi, J. (2006). Programtanterv a „Mesemondóka“ címü programcsomaghoz az 1-6. évfolyamra. In Idegen nyelvi kompetenciaterület: Koncepciók és programtervek (pp. 31-78). Sulinova Kht.

Vargha, K. \& Rónai, B. (1973). Der schlaue Bergmannsknappe. Märchen der Bergleute aus dem Komitat Baranya (Südungarn). Demokratischer Verband der Deutschen in Ungarn .

Zenker-Starzacher, E. (1941). Eine deutsche Märchenerzählerin aus Ungarn. Hoheneichen-Verlag.

Zenker-Starzacher, E. (1956). Es war einmal / Deutsche Märchen aus dem Schildgebirge und dem Buchenwald. Prodomo-Verlag.

Zenker-Starzacher, E. (1986). Märchen aus dem Schildgebirge. Deutsches Erzählgut aus Ungarn. Carinthia. 


\section{Internetes források}

Steh dazu! A Magyarországi Németek Országos Önkormányzata stratégiája 2020. Budapest. http://www.ldu.hu/attachments/file/573d8e26ce468a18540001c9

17/2013. (III. 1.) EMMI-rendelet a nemzetiség óvodai nevelésének irányelve és a nemzetiség iskolai oktatásának irányelve kiadásáról. http://www.kozlonyok.hu/ nkonline/MKPDF/hiteles/MK13035.pdf

A német nemzetiségi nevelés-oktatás kerettantervei. https://www.oktatas.hu/kozneveles/ kerettantervek/2020_nat/nemzetisegi_neveles_oktatas_kerettantervei/nemet

Tantervek, tanmenetek. http://www.udpi.hu/hu/tantervek, http://www.udpi.hu/de/ tantervek

Ungarndeutsches Pädagogisches Institut, www.udpi.hu

https://hu.wikipedia.org/wiki/Palkonya 
Márkus, É.

\section{The use of German folk tales from Baranya county in education}

The study introduces the volumes of folk tales of the Germans in Hungary (Angéla Korb, Josef Michaelis, Ede Herger, Elli Zenker-Starzacher), and then delves deeper into the German folk tales of Baranya county through the presentation of the storybook Devil's Peak (Teufelsgipfel). It highlights some of the motifs of the folk tales, introducing, inter alia, typical characters and scenes form the tales. It goes on to outline the role of folk tales in ethnic minority education, analysing the documents that play a role in the education of Hungarian Germans (Roots and Wings, Curricula and Framework Curricula, EMMI Decree 17/2013). Finally, the study also discussed the modern methodology of teaching tales in primary school.

Keywords: German minority in Hungary, folk tale, minority education, Baranya county

Márkus Éva: ORCID: https://orcid.org/0000-0002-3571-8472 